\title{
What Is The Most Effective Method Of Integrating Ethics Into The Accounting Curriculum In The Post-Enron Environment?
}

Constance J. Crawford, (E-mail: ccrawfor@ramapo.edu), Ramapo College of New Jersey

\begin{abstract}
Should ethics be taught as a separate accounting course or woven through the entire accounting curriculum? Research indicates that ethics has always been part of the accounting curriculum; unfortunately, AACSB does not require one separate course in ethics before graduating from undergraduate and MBA programs. In response to the overwhelming amount of recent accounting scandals, most accounting professors are simply applying the Enron case to illustrate audit failure. However, many professors question whether ethics can be taught, as ethical behavior is formed before students attend college. Empirical evidence supports this position.
\end{abstract}

\section{Introduction}

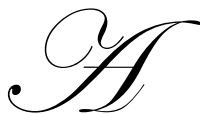

re accounting programs really the cause of the departure of moral values from accounting? Many researchers have concluded that instruction in ethical behavior has diminished gravely as accounting programs have become primarily technical (R. Madison, 2003). Currently, colleges and universities have expanded their programs to 150 credit hours to incorporate the overwhelming number of regulatory pronouncements (R. Smith, 2003). Many in the accounting profession feel it is difficult to teach accounting graduates about ethics until they enter the "real world" (Madison, 2003).

Currently, no unified model/framework exists capturing all factors influencing ethics in business environments and in the accounting curriculum. Educators are frantically rewriting their curricula to educate their students' ability for making accurate ethical decisions (D. Piller, 2003). Accounting education is attempting to find effective methods of preparing the next generation of CPA's. The events at Enron, Worldcom, Adelphi, and Arthur Andersen have forced accounting educators to enhance their pedagogy on ethical issues (B. Mader, 2003). Accounting curricula are becoming more diverse, but unfortunately there is no central model.

Many academic institutions are striving for The Association to Advance Collegiate Schools of Business Accreditation, (AACSB), which requires the inclusion of ethics into the curriculum, but does not require one separate course in ethics(R. Joss, 2003). There are many strong arguments supporting the premise that professional ethics should be taught (Van Peursem and Julian, 2003). Accounting education must not only develop accounting skills, but enable students to develop ethical standards. Ethics education can enhance a students' ability to understand the need for ethical professional standards (J. Mackey 2003.).

Some researchers conclude that ethics education is unnecessary because law and professional regulation are sufficient to determine acceptable behavior (McDonald and Dunleavy, 1995). Others believe in the free-market theory of Milton Friedman which discourages government intervention. But unfortunately, the current business environment indicates that prior ethical training has failed to enable business managers to recognize the link between ethical decision-making and real life behavior (Helps, 1994). 


\section{Ethics and the Accounting Profession:}

Accountants view themselves as professionals who serve as the conscience of the business community. The purpose of ethics in business is to direct business men and women to abide by a code of conduct that facilitates, if not encourages, public confidence in their products and services (Smith, 2002). Accounting has historically been built upon a foundation that embraces integrity, professionalism and skill (McDonald, 2003). The behavior of the Arthur Andersen auditors has made many questions whether accounting is an honorable profession.

Ethical standards have changed tremendously in the last century (J. Samuelson, 2003). Ethics provide the moral conscience and foundation upon which our society rests. The Enron debacle further illustrates that without an ethical foundation, corporations fail. Ethics is the framework for professionals to foster public confidence, but good ethics does not always mean profitable business. The business environment of today promotes the philosophy: "anything goes". The Enron scandal is symptomatic of a breakdown of the ethical values of business over a period of the past 20 years (Julian and Van Peursem, 2003).

The question which faces many in the accounting professions is simply: "Can ethics be taught?" There are many researchers that indicate the breakdown of the American family is associated with the decline in ethical values in society today (K. Smith, 2003). Research in the field of ethics as related to business professionals needs to be expanded (G. Robson, 2002). Ethical considerations may be taking a back seat to the bottom line, as managers manipulate numbers for the sake of higher profits (A.Sachdev, 2003).

Research has indicated that many managers and executives are unclear about their ethical standards (J. Beever, 2002). Accounting is in an unstable environment, as members are faced with the reality that "to err is human". People are not born with ethical values, it is a learned response. A formal ethics program is probably the best way to succeed in empowering business from distinguishing between the ethical and the merely legal (J. Samuelson, 2003).

\section{How Ethics Is Currently Taught}

The events at Enron and Arthur Andersen have forced accounting academics to increase the focus on ethical issues (Robson, 2002). Accounting curricula are becoming more diverse, but there is no dominant model focusing on ethics inclusion. More than 150 business professors and ethics officers petitioned the Association for the Advancement of Collegiate Schools of Business (AACSB), to require at least one ethics course be required as a condition for accreditation. Unfortunately, AACSB failed to require even one course in ethics; instead they recommend ethics as an area of inclusion in the curriculum. The accreditors want to leave the decision up to the school (A. Sachdev, 2003). The orphaning of ethics coursework is one of the best-kept secrets of business education.

Many researchers have concluded that accounting programs have become largely technical in nature. In a survey conducted by the Ohio State Society of CPAs determined that undergraduate students in Ohio colleges receive approximately 10 hours of classroom-based ethics education (Madison, 2002). The students stated their greatest exposure to ethics is in auditing, intermediate accounting and introductory accounting classes.

Pepperdine University's School of Business has been ranked top as in the world by Business Week magazine for teaching ethics to executives. The program includes a visit to a prison for "white collar criminals." There are approximately 20 colleges across the country expanding their accounting curriculum to include teaching students on how to determine whether the accounting staff is "cooking" the books. The University of California at Irvine has created a two- credit course on Enron which will focus on the fraudulent financial statements. Students at the Massachusetts Institute of Technology are studying the failures at Tyco International, Global Crossings and Xerox. At the University of California, Davis, incoming MBA students were required to participate in a mandatory "ethics boot camp". 
At Villanova University, there has been a long-standing commitment to ethics. Undergraduates take ethics in their first two years as part of the core curriculum. Students may also complete an ethics concentration. At the M.B.A. level, students must complete a half-year business ethics course in their first year.

At the University of Michigan Business School, students were required to write a case study on the most challenging ethical dilemma each had faced. The University of Chicago is redesigning a required leadership course to include an ethics component. Texas A \& M University brought in an auditor from Arthur Andersen's Enron team as part of the school's Education outside the Classroom, to discuss how the auditing firm was ruined as a result of the Enron fraud. The Stanford Graduate School of Business has developed a four-part "Ethics Curriculum". The Wharton School of the University of Pennsylvania has created a "Wharton Ethics Program", and invited Sherron Watkins, the Enron whistle-blower, to speak to the classes. They are also developing a Ph.D. in business ethics starting in 2004.

Perhaps, Harvard Business School was the institution most embarrassed by the role their school's alumni played in the recent corporate scandals (R.Carlo, 2002). Harvard has ordered a review of the school's ethics curriculum. The mandatory ethics course has been extended from three weeks to the entire semester and incorporates examples from the past year's scandals.

Most business educators acknowledge that it is unrealistic to expect an accounting or economics professor to make more than a cursory inclusion of ethics in their curriculum (A. Sachdev, 2003). Researchers recognize that many business schools already offer a stand-alone ethics course, but most do not require enrollment as a requirement of graduation. At Rutgers, ethics used to be a mandatory class for undergraduates, however as international business became the focus during the 1990's; it squeezed out ethics as a requirement.

A survey was conducted by Educational Directories Unlimited to determine what impact the Enron debacles had on MBA students (J. Meinhardt, 2003). The survey questioned prospective MBA student's educational needs. More than eighty percent of the respondents stated MBA programs need to place a greater emphasis on ethics (J. Meinhardt, 2003). Many students, who participated in a survey conducted by the Aspen Institute, stated their concerns regarding questionable values taught in class that may later contribute to mismanagement or fraud. Only twenty-two percent of the participates said their schools were doing "a lot" to prepare them for conflicts involving mismanagement or fraud. The study, entitled, "Where Will They Lead? M.B.A. Student Attitudes about Business \& Society 2003" included 1,693 participants from Columbia Business School, Yale School of Management, the Wharton School and the London Business School. Twenty percent of the respondents did not feel they were receiving any ethics training and more than half felt the priorities and messages taught in M.B.A. programs probably contributed to the recent scandals.

In a 2003 Global M.B.A. Graduate Survey on Ethics in Business School Curriculum, respondents were asked how effectively ethics is incorporated in their graduate business curriculum (Graduate Management Admissions Council, 2003). Only nine percent felt ethics was incorporated extremely effectively, thirty percent felt it was incorporated very effectively, forty-one percent stated it was incorporated somewhat effectively, and twenty percent felt it is not very or not at all effectively incorporated. The research determined that full-time programs offered the greatest exposure to ethics through speakers (60\%), followed by required courses (47\%), integrated case studies $(43 \%)$, and references to ethics in most courses (43\%). Graduates of executive programs rate the effectiveness of the incorporation of ethics significantly higher than graduates of full-time and part-time programs.

\section{The CPA Profession and Ethics}

Issues of accounting and professional ethics are widely discussed in the professional and academic literature. According to the professional literature, accounting education must not only develop students' skills and knowledge, but it must also instill in students the ethical standards and commitment of a professional (K. Van Peursem and A. Julian, 2003). However, some members of the business community believe that ethics education is unnecessary because law and professional regulation are sufficient to determine what acceptable behavior is. They 
feel that requiring students to learn professional regulations and guidelines in order to pass ethical exams does not ensure that they will retain a concept of ethical behavior.

Other members of the accounting community believe that professional ethics education may only improve ethical behavior in those members who want to act ethically. Many accountants believed that classroom exposure to accounting ethics may prepare you to better handle ethical dilemmas encountered during an audit (Van Peursem \& Julian, 2003).

The American Institute of Certified Public Accountants states that a significant portion of the CPA exam is based on the "understanding and interpretation of ethical standards" (Mader, 2002). During the 2003 Ohio Accounting Show, a three hour continuing professional education course entitled, "Ethics and Professional Standards for CPAs" was introduced. The course is designed to meet the new Accounting Board Organization requirement for three hours of continuing ethics education starting in 2004.

The Chicago-based Practice Development Institute, Inc., a 23,000 member trade group, has issued a proposal calling for CPAs to receive no less than four hours of ethics training as a means to restore confidence in the accounting profession (A. Sachdev, 2003). A small group of accounting practitioners and academics has started an organization called Association for Integrity in Accounting (AIA). They have determined that one of their primary goals is to redeem accounting education (P. Williams, 2003). They want to begin debate on what is missing from the accounting curriculum The AIA believes that the most culpable institution in the current environment of corporate corruption is academia.

\section{Government Regulation and Ethics}

The Enron-Andersen incident has forever changed the face of the accounting profession. On July 20, 2002 the Sarbanes-Oxley "Corporate Responsibility" Act was signed into law. Title I of the Sarbanes-Oxley Act created the Public Company Accounting Oversight Board, which is independently funded by publicly held companies and overseen by the SEC. One of the duties of the Oversight Board is to establish ethics standards related to the preparation of the auditing reports (T. Herron \& D. Gilbertson, 2003). The Board must make annual inspections of firms auditing more than 100 public companies. The board requires that registered public accounting firms expressly state, in each public company audit report, that the audit was conducted in accordance with the standards of the Public Company Accounting Oversight Board as of January 1, 2004.

The Sarbanes-Oxley Act requires management to be more involved in the annual report. CEOs and CFOs must now certify the annual reports. As part of the act, the SEC is required to conduct a study on the adoption of principles-based accounting standards in the United States.

The Sarbannes-Oxley Act also creates protections for "whistleblowers". Publicly traded corporations are mandated to set up procedures for anonymous reporting of fraud allegations. The act establishes a corporate culture of "zero" tolerance and imposes new criminal penalties relating to fraud, conspiracy, and interfering with investigations. The act places a higher scrutiny on Chief Executive Officers and Board of Director members. The act reinforces the idea that ignorance of the law does not excuse violation.

The SEC has three years to hire approximately eight hundred accountants, attorneys and other professionals necessary to implement Sarbannes-Oxley. Congress has increased the SEC's budget by 63 percent in 2003, (M.Perin, 2003).

The International Federation of Accountants (IFAC) recently completed a four- year study to re-write its Code of Professional Ethics for auditors (T. Herron \& D. Gilbertson, 2003). The chair of the IFAC Ethics Committee "highlighted" the need for clear and unequivocal accounting and auditing standards based on principles, not rules (New York State, 2002, 1). 


\section{Methodology}

I used a survey to investigate student's perceptions concerning the most effective method of incorporating ethics into the accounting curriculum. Part one of the survey consisted of 20 questions regarding ethics and the curriculum. The participants were asked to respond to the questions using the following scale: $1=$ strongly disagree, $2=$ disagree, $3=$ no opinion, $4=$ agree and $5=$ strongly agree. The second part requested demographic information. The survey was distributed to undergraduate and graduate accounting students at Ramapo College of New Jersey and Fordham University, who attend both day and evening classes. Both schools have a diverse student population, with many full-time juniors and seniors involved in internships at large multi-national corporations and the "Big 4" accounting firms.

\section{Survey Measures}

The survey attempted to measure the most effective method of integrating ethics into the business school curriculum. Research has indicated that ethics has always been a component of the curriculum, and the survey attempted to determine how effective that integration has been. Four questions focused on participants' gender, age, ethnicity, and professional experience. Four questions elicited student's ethical training and background. Two questions requested the participant's opinion on how well the accounting ethics in the business curriculum had prepared them. The focus of the survey was two-fold. First, I wanted to determine if the students felt the accounting curriculum had an adequate ethical component and second, to determine if the lapse in ethics at Arthur Andersen and Enron had impact their decision to major in accounting.

Specific questions concerning the type and amount of ethical training were used to uncover attitudes about the adequacy of ethics in the current accounting curriculum. For example: I learned a sufficient amount of ethics in my accounting classes; what type of ethics course did you take; and, Ethics is discussed most in which accounting course?

\section{Survey Respondents}

The questionnaire was distributed to graduate and undergraduate accounting students at Ramapo College of New Jersey and Fordham University. Fifty-eight percent of the respondents were female and forty two percent were male. Eighty percent of the students were undergraduate students of traditional age (18-22) and twenty per cent of the students were graduate students, over the age of twenty five. Eighty percent of the respondents were white, thirteen percent were Asian, and seven percent were Hispanic. Seventy- seven percent of the students had related work experience and twenty three percent of the respondents had no prior work experience.

\section{Survey Results}

The first part of the survey focused on the opinions of the participants regarding ethics as a curriculum requirement. In response, $95.7 \%$ of the students agreed that ethics should be a requirement for all business students. A majority of students, 93.6\%, agreed that ethics should be taught from a business perspective rather than a philosophical viewpoint. The respondents overwhelmingly agreed, $76.5 \%$ that a separate course in accounting ethics should be incorporated as a requirement in the accounting program and $93.6 \%$ agreed that ethics should also be integrated throughout the business curriculum.

Student's opinions concerning the ethical training they were receiving at their academic institutions varied. In response to the question, "My school is doing 'a lot' to prepare me to handle ethical dilemmas in a work environment", only $27.6 \%$ agreed, $36 \%$ had no opinion, and $36 \%$ disagreed. Accounting classroom discussion involving ethical decision-making has increased dramatically since the current Arthur Andersen debacle, with 91\% of the students agreeing. In response to the question, "We do not discuss business ethics enough in my accounting classes," $42.5 \%$ agreed, $27.6 \%$ had no opinion, and $29.7 \%$ disagreed. Whether students believe they are learning a "sufficient" amount of ethics in their accounting education, 36\% agreed, $32 \%$ had no opinion, and $32 \%$ disagreed. 
In contrast, in response to a specific question regarding the adequacy of ethics in the accounting curriculum, $60.8 \%$ indicated it was "too little," while only $39.2 \%$ felt it was adequate. None of the students selected "too much," in response to that question. The students were asked specifically, in what course they had learned the most about ethics, $47.7 \%$ cited Auditing, 22.7\% Intermediate Accounting, 20.4\% Principles of Accounting, and 9\% stated Managerial Accounting. When asked "how often" ethics was discussed in accounting courses, $6.6 \%$ stated constantly, $37.7 \%$ often, $40 \%$ occasionally and $15.5 \%$ rarely.

The majority of participants had studied ethics from a business perspective, $75.5 \%$, while $20 \%$ had studied ethics as part of the general education curriculum, and only $4.5 \%$ of the students stated they had not taken an ethics course. The students were asked to respond to the statement, "You need business experience in order to comprehend ethical problems," $51 \%$ agreed and 36\% disagreed.

The students were also surveyed regarding their opinion on ethics as it pertains to the business community. When asked if accountants are the most ethical of all professionals, $0 \%$ agreed, 53\% had no opinion and $44.6 \%$ disagreed. Interestingly, when asked if ethical training is more important for accounting majors than for other business majors, $23 \%$ agreed and $66 \%$ disagreed. When surveyed as to whether their decision to major in accounting had been impacted by the recent ethical lapses, $17 \%$ agreed, $29.7 \%$ had no opinion and $51 \%$ disagreed. Students were asked if they would enroll in an accounting ethics course, 76.5\% agreed, $17 \%$ had no opinion, and $6.5 \%$ disagreed. Finally, in response to the statement, "Failure to properly teach accounting ethics caused the recent increase in fraudulent financial statements," $27.6 \%$ agreed, $32 \%$ had no opinion and $40 \%$ disagreed.

The debate over whether ethics can actually be taught and what is the best way to achieve a desired outcome was also incorporated into the survey. The students were asked to respond to the statement, "Ethics cannot be taught," $9 \%$ agreed, $21 \%$ had no opinion and 70\% disagreed. In response to the statement, "Ethical training is most effective when learned at an early age," $72.3 \%$ agreed, $10 \%$ had no opinion and $14 \%$ disagreed.

The last topic pertaining to ethics, concerned society and ethical behavior. When asked to respond to the statement, "Society does not agree on what constitutes ethical behavior," $48.9 \%$ agreed, $25.5 \%$ had no opinion and $25.5 \%$ disagreed. In response to the statement, "What is 'right and wrong' depends upon cultural diversity," $63.8 \%$ agreed while $25.5 \%$ disagreed. Students were asked whether they believed standards of ethics were declining, $44 \%$ agreed, $29.7 \%$ had no opinion and $25.5 \%$ disagreed. Asked whether CEO's behave in an ethical manner, only $8.5 \%$ agreed, $46.8 \%$ had no opinion and $36 \%$ disagreed.

\section{Conclusions}

The need to incorporate more ethics into the accounting curriculum is apparent, even though $93.4 \%$ of the students had taken an ethics course. An overwhelming majority of the participants indicated that ethics was discussed "too infrequently" in their accounting courses, which corresponds to prior research. Most respondents indicated the need for a separate accounting ethics course, but also, that ethics should be incorporated routinely throughout their educational experience. Prior research concurs with my findings, that auditing and intermediate accounting is the courses that integrate ethics most frequently. Another finding of note is that the majority of students are currently learning ethics from a business rather than philosophical perspective. Most students either had no opinion or did not feel they had learned a sufficient amount of ethics in their accounting classes.

The selection by the students of "no opinion" in response to many of the statements concerning ethics in the accounting curriculum indicates that the students are "confused". They did not believe that accountants are more ethical than other professionals, but then also stated that ethics is not more important for accountants than for other professionals. The students felt that ethics in accounting were declining, but almost $30 \%$ had no opinion. Just as many students had no opinion concerning society's confusion regarding "right and wrong" ethical behavior as those that disagreed. It is important to acknowledge, that a majority of students believed ethics could be taught, but at a young age. 
Accounting programs on both the undergraduate and graduate level need to respond more quickly to the business environment. Educators should set the example of how to teach ethics so that the emerging business leaders will no longer be "confused" as to what constitutes ethical behavior. Business schools need to listen to what the research is saying; ethics in the accounting curriculum must be significantly increased. A separate accounting ethics course should be a requirement for both an undergraduate and graduate accounting degree.

Unfortunately, prior research results have not been incorporated into the accounting curriculum. My survey produced similar responses to those conducted in 2000, prior to the Enron and Arthur Andersen demise. The purpose of academic research is to enable educators to enhance curriculum in response to research findings. The importance of ethics to the accounting profession is irrefutable. Academics are failing to listen to their own research, their students and the business community. Perhaps, the accounting educators lack ethics as well.

\section{References}

1. Beck, E. (2003). In the wake of Enron, accounting is hip and enrollment is up. Young Bloods. February/March 2003. Retrieved from http://s6.ixquick.com.

2. Beever, J. (2002). Who's watching the big 5? On consulting and ethic.New Incite Marketing Analysis and Design. January 2002. Retrieved from http://www.newincite.com/articles.

3. Bennett, E. (2003). Area business schools update ethics curriculum. Philadelphia Business Journal. July 28, 2003. Retrieved from http://philadelphia.bizjournals.com/phiadelphia/stories/2003/07/28/focus4.html .

4. Browning, L. (2003). Ethics lacking in business school curriculum, students say in survey. The New York Times. Retrieved from http://www.nytimes.com/2003/05/20/business/20ETHI.html .

5. Bui, T and Sankaran, S. (2003) Ethical attitudes among accounting majors: An empirical study. Journal of American Academy of Business. 3 (1/2) 71. Retrieved from http://proquest.umi.com/pqdweb.

6. Carlo, R. (2002). Business ethics 101.Boundless Webzine. Retrieved from http://www.boundless.org/2002.

7. Carozza, R. (2002). Accounting students must have armor of fraud examination. The White Paper. 2002.

8. Conway, G. and Gribbon, K. (2003) Sarbanes-Oxley: Legislating morality or mandating change? Consequences of 2002 law are considerable. [Electronic version]. Retrieved from http://www.localtechwire.com/article.cfm?u

9. Gilbertson, D., and Herron, T. (2003) Ethical Principles vs. ethical rules: The Moderating effect of moral development on audit independence and judgments. Eighth Symposium on Ethics in Accounting. (June).

10. Foster, J. and Johnson, C. (2000). Reforming accounting curriculum using authentic assessment: A research paper with a proposed case study. Retrieved from http://www.winwinpartner.com .

11. Frederick, W. and Swanson, D. (2003). Business education puts corporate reputations at risk. The Corporate Citizen. November 2003, Vol. 3 (3).

12. Joss, R. (2003). Sanford Graduate School of Business: A multi-layered approach to teaching ethics. AACSB International. Retrieved from http://www.aacsb.edu/publications/enew .

13. Julian, A. and Van Peursem, K. (2003) Ethics education and the accounting curriculum can ethics be taught? [Electronic version]. Retrieved from http://216.239.39.104/ custom?q=cache:_Pde6BbK2A8J:aaahq.org/AM2003/EthicsSympoium

14. Kelly, M. (2003). It's a heckuva time to be dropping business ethics courses. Business Ethics. Fall 2003. Retrieved from http://www.business-ethics.com/BizSchl .

15. Mader, B. (2002). Enron case causes colleges to champion accounting ethics. The Business Journal. Retrieved May 6, 2002, from http://www.bizjournals.com/milwaukee/s.

16. Madison, R.. (2002). Is failure to teach ethics the causal factor? Strategic Finance. Retrieved December 18, 2002, from http://www.smartpros.com/x36364.xml.

17. Mackey, J. and Vangermeersch, R. (2003). Failure of the new business environment and concepts. The CPA Journal. July 2003.

18. McGaw, N. (2003). USA: Ethics lacking in business school curriculum, students say in survey. The New York Times. May 20, 2003. Retrieved from www.nytimes.com .

19. Meinhardt, R. (2003). Survey shows MBA programs. The Business Journal Tampa Bay. Retrieved February 24, 2003 from http://tampabay.bizjournals.com/tampabay/stories/2003/02/24/focus3.html Perin, M. (2003). Local recruiting firm lands massive SEC hiring project. 
20. [Electronic version]. Retrieved from http://houston.bizjournals.com/houston/stories/2003/11/10/ story7.html

21. Piller, D. (2003). Business schools put new emphasis on ethics. Star-Telegram. Retrieved September 14, 2002.

22. Robson, G., Savage, H. and Shaffer, R. (2002). Accounting education: Changing skill sets to meet modern needs. Catalyst (2002). Dublin: Jul/Aug. 2003 Retrieved from http://proquest.umi.com .

23. Samuelson, J. (2003). Business ethics after Enron. Ford Foundation Report Online. Retrieved from http://www.fordfound.org/publication.

24. http://www.dfw.com/mld/dfw/business/6772728.htm.

25. Sachdev, A. (2003). CPA group urges ethics instruction. Chicago Tribune, Feb., 2003, pg. 3. Retrieved from http://proquest.umi.com.

26. Sachdev, A. (2003). Ethics moves to the head of the class. The Chicago Tribune. February 14, 2003. Retrieved from http://www.chicagotribune.com/business .

27. Sirard, J. (2003). Ethics session greets UCD business students. The Sacramento Bee Retrieved September 23, 2003, from http://www.sacbee.com/content/business/story .

28. Smith, K., and Smith,L. (2003). Business and accounting ethics. [Electronic version]. Retrieved from http://s10.ixquick.com

29. Smith, R., (2003). Business schools now stressing ethics as part of everyday business when there are no rules. Athens Banner-Herald. Retrieved from http://216.239.41..104/ custom?q=cache:GV1 ofzxoovaj:www.athensnewspapers.com.

30. Thomas, C. (2003). Enron and beyond: What's the WorldCom'ing to? The CPA Journal. January 2003. Retrieved from http://s7.ixquick.com .

31. Weber, J. (2003). Emphasizing ethics across the business curriculum at Duquesne University. The Ethics News. Retrieved October 20, 2003, from http://www.bus.duq.edu/Beard/EthicsNews/story5.htm.

32. Williams, P. (2003). Association for integrity in accounting enters the discussion Of accounting reforms. The CPA Journal. Apr. 2003. vol. 73 (4) 14-15.

Notes 